\section{Time: research necessities make it hard to keep track}

SIR — Plans to impose effort-reporting on scientists, as mentioned in your Editorial 'On the paper trail' and News story 'Researchers criticized for poor time-keeping' (Nature 449, 508 and 512-513; 2007), will be difficult to implement. In practice, it is almost impossible to give an accurate estimate of effort, because scientists are rarely off the job, even when asleep. If they are not actually doing a particular task, they are planning the next, or puzzling over the most recent observation. How should that time be counted? In most research, the edges of a project are only known indistinctly. So in many cases it is difficult to know when one has wandered from one project to another or into an unfunded area.

The definition of ' $100 \%$ effort' causes another problem. This metric tends to be based on a 40-hour week, but not many funded scientists can afford to do so little work - 80 hours ( $200 \%$ effort?) is more common. Also, in these days of tight budgets, how should the project director account for the time spent on writing and revising new grant applications? Under the current funding system, a very large fraction of time is spent on this activity.

Finally, it must be recognized that bootstrapping a new project with the funds of an existing project is built into the system. If there is no venture capital available, new grants have to be built on the backs of existing ones. After all, that's how they got funded in the first place. When was the last time a new proposal was funded in the absence of any preliminary data?

There may be some abuse in very large labs with multiple sources of funding. Filling in the blanks on applications and enforcing appropriate effort reports should be the norm. But please don't reduce the time available for research still further by making researchers account for every moment. Robert J. O'Connell

Brudnick Neuropsychiatric Research Institute, 303 Belmont Street, Worcester,

Massachusetts 01604, USA

\section{Time: accounting problems caused by Caltech system}

SIR - You report on a National Science Foundation (NSF) audit of Caltech's accounting system in your News story 'Researchers criticized for poor time-keeping' (Nature 449, 512-513; 2007). The audit cited accounting deficiencies, in particular the handling of professorial effort as "voluntary committed cost sharing" as opposed to "voluntary uncommitted cost sharing".
Although faculty and staff were following the Caltech accounting practices that were in place at the time, your News story states that researchers "failed to report this to Caltech's payroll system". In fact, we did not have that option because of the deficiencies in the system. The audit report did state that "Caltech's responses, once implemented, should address our audit recommendations".

Although the NSF report discusses interviews and facts related to several principal investigators and their grants, it does not name individuals. Even though the report does not refer to me by name, your News story associates information in the report with me personally. The NSF auditor, Joyce Werking, incorrectly recorded my statements about my time allocation in the report. The statements about me in your article are erroneous, taken out of context and unfair to me. Although Nature did attempt to contact me during the week before going to press, I was away at the time and unable to respond.

Certainly, Caltech and other universities should increase their efforts to align their accounting practices with agency regulations. Also, NSF should improve its methods for gathering and accurately reporting information. And Nature could have presented a more informed, responsible and balanced view.

Robert D. McKeown

Department of Physics, Mail Code 106-38, California Institute of Technology, Pasadena, California 91125, USA

\section{Turkish science suffers as government vies with law}

SIR - Praise for the present Turkish government's work in fostering good science, in your Editorial 'Turkey's transformation' (Nature 449, 116; 2007), reads to my eyes like a cruel joke in the face of what is really going on in the country. It is true that the current government has increased the budget placed at the disposal of Tubitak, the main research agency under government control. It did so, however, by slashing the budgets of the independent universities.

Tubitak's new administration was appointed in a manner that was decreed illegal by the Turkish courts. As a result, the Turkish Higher Education Council advised the universities not to have any dealings or communication with Tubitak, because of the legal status of its administration. Therefore, no Turkish scientist can legally use a penny of the increased research budget. That some do use it, in violation of the law, is an act of desperation, because few other sources are left that can be used to sustain research and support students. For example, I had already had two projects accepted when the present administration was unlawfully appointed but I withdrew them immediately; since then I have had no interaction with Tubitak.

The bad health of Turkish science is further demonstrated by the party-political appointments made by the government within organizations such as the Geological Survey and the Atomic Energy Commission, as well as many senior and junior academic posts, which are not made on the basis of scientific merit. Many of these appointments are being challenged in the courts. Another source of serious headache for Turkish science is the minister of education's sympathy for 'intelligent design', and the way that evolution is taught in our country.

A. M. Celâl Sengör

Istanbul Technical University,

Eurasia Institute of Earth Sciences and

Department of Geology, Faculty of Mines, 34469 Istanbul, Turkey

\section{Explorers' challenge sunk by Arctic warming}

SIR - The so-called Northwest passage (between the Pacific and the Atlantic) has become fully navigable, as mentioned in your News story 'Arctic melt opens Northwest passage' (Nature 449, 267; 2007). It is worth recalling that when Roald Amundsen led an east-west expedition through the Northwest passage on the ship Gjøa, it took him two and a half years to reach Gjøahaven (now called Gjoa Haven) in mid-August 1905. He wrote in his diary: "The North West Passage was done. My boyhood dream - at that moment it was accomplished. A strange feeling welled up in my throat; I was somewhat overstrained and worn - it was weakness in me — but I felt tears in my eyes."

In June 1940, the Royal Canadian Mounted Police vessel St Roch left Vancouver to sail the passage from west to east. It docked at Halifax on 11 October 1942. In 1944, the St Roch returned to Vancouver by a more northerly route, cutting the time down to just 86 days. More recently, icebreakers and icestrengthened ships have on occasion traversed the route. But by the end of the 2007 melt season, a standard ocean-going vessel could have sailed smoothly through, proof indeed that the Arctic summer ice is rapidly diminishing.

A. J. (Tom) van Loon

Geological Institute, Adam Mickiewicz University, Maków Polnych 16, 61-606 Poznan, Poland

Contributions to Correspondence may be submitted to correspondence@nature.com. Published contributions are edited.

Science publishing issues of interest to authors are regularly featured at Nautilus (http://blogs.nature.com/nautilus), where we welcome comments and debate. 